Available online at

\title{
Strategy To Reduce Traffic Jams On Piet A. Tallo Street, Kupang City
}

\author{
A. Wadu ${ }^{1 *}$, A. A. Tuati ${ }^{2}$, M. R. Sodanango ${ }^{3}$.

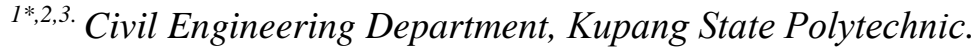 \\ Email: ${ }^{1 *}$ awd.ub15@gmail.com.
}

A R T I C L E I N F O

\author{
Article History : \\ Article entry : :16-08-2020 \\ Article revised : 01-09-2020 \\ Article received : 16-09-2020
}

Keywords :

Capacity, Road, Traffic, Urban.

IEEE Style in citing this article : [1] X. Wu and X. Du, "Research and Practice on Equilibrium Theory of Road Capacity," Procedia - Soc. Behav. Sci., 2013, DOI: .1016/j.sbspro.2013.08.172.
A B S T R A C T

Problems when the flow of traffic on urban roads exceeds the capacity of the road resulting in traffic jams. It happened on the Piet A. Tallo street during peak hour conditions. Especially in converted type of route from $4 / 2 \mathrm{~T}$ to $2 / 2 \mathrm{TT}$, which results in a buildup of traffic flow at that point. This research aims to analyze the volume to capacity ratio $(\mathrm{v} / \mathrm{c})$ and provide recommendations for long-term strategies to reduce traffic jams on Piet A. Tallo Street. Traffic flow and capacity analysis based on Guidelines for Indonesia Road Capacity 2014 (PKJI2014), while the projected growth in the number of vehicles in the next 20 years, uses the linear regression method. The results show that peak traffic flow exceeds road capacity in the $2 / 2 \mathrm{TT}$ segment with a v/c ratio of 1.08. Recommendations for handling this by regulating side friction and changing road segment type $2 / 2 \mathrm{TT}$ to $4 / 2 \mathrm{~T}$. Using linear regression projected traffic flow in 2040, road capacity can still serve traffic flow with a maximum v/c ratio of only 0.93 .

\section{Introduction}

Low road capacity design, especially in road construction that cannot keep up with traffic volume growth, results in low service levels and low capacity to accommodate traffic, resulting in increased traffic congestion on urban roads [1]. The cause and effect relationship between road capacity requirements and land use development is very influential with the development of housing areas of $21.9 \%$ and expansion of work areas of $24.8 \%$, resulting in an increase in traffic volume by $22-30 \%$ [2].

Kupang City is the capital city of East Nusa Tenggara Province. It has economic, trade, and educational growth, which is increasing from year to year. The population growth rate in 2010-2017 was 2.97\%, with an economic growth rate in 2017 of 6.83\%[3]. Therefore, it needs to be balanced with adequate infrastructure to meet the increasing needs of Kupang City citizens. 
The number of vehicles in Kupang City that increases every year can cause severe traffic jams in the next few years. The latest data on the growth in the total number of vehicles in Kupang City has increased by $7.99 \%$ each year, with the most massive percentage increase occurring in the types of motorbikes at $8.22 \%$, [4]. The increase in the number of vehicles causes an increase in traffic flow movement, which is not matched by an increase in infrastructure, causing congestion. One of the congestion points in Kupang City that often occurs during peak hour is the Piet A. Tallo street.

The Piet A. Talo street has a reasonably high traffic volume. This section is a meeting place for vehicles from Oesapa, Oebufu, Mayor, and Penfui district. Besides, this road section also connects some universities in NTT and the Kupang Regency Government Center in Oelamasi with the downtown area of Kupang, which is where most students and employees of the Kupang district government domiciled. The high volume of traffic with a heterogeneous traffic flow that passes on this road occurs during the morning, afternoon, and evening rush hours, resulting in severe congestion on this section. In the study, road capacity decreased significantly due to platoon formation when mixed traffic was occupying lanes with speeds lower than the desired operating speed than curbside lanes during their operation on the intercity highway. The increasing volume of vehicles passing through this road section and a change in the type of road from 4 lane 2 way divided (4/2T) to 2 lane 2 way undivided (2/2TT) at STA $00+135.60$ to STA $00+530.62$ results in a reduction in road capacity resulting in congestion during peak hour. The traffic flow on urban roads is designed for high-speed movement, but the heterogeneity of traffic, non-lane-based movements results in a reduction in overall vehicle speed under certain conditions [5]. This results in service level for road users needing attention, especially in the smooth flow of traffic [6]. Necessary to prepare an appropriate strategy to reduce traffic congestion on a poorly performing road when heavy and unstable traffic, and to understand the pattern of routine traffic conditions on Piet A. Tallo Street which will changes traffic performance patterns to be better [7]. Therefore, this study aims to provide strategic recommendations for increasing the road's capacity so that it can meet traffic needs for a long period of up to 20 years on the Piet A Tallo Kupang street. 


\section{Literature Review}

\subsection{Roadway Geometric.}

Road conditions can consist of various geometric parameters describing the road, such as type of facility, lane width, shoulder width, and horizontal and vertical alignments. Horizontal alignment, especially the characteristic of horizontal curves, can have a large impact on traffic flow [4]. Horizontal alignment consists of straight (tangent) elements or curved elements. Each of these elements has its own achievable geometric characteristics. Therefore, the capacity flow can vary from one element to another. These data are collected directly from the site survey, which includes lane width, lateral distance, number of lanes in each direction, median width, and sidewalk and shoulder width.

The study was conducted by Semeida 2013 with the title. New models to evaluate the level of service and capacity for rural multi-lane highways in Egypt, [8]. This indicates that the variable that most influences road capacity is lane width, followed by the median width. The increase in lane width from $3.6 \mathrm{~m}$ to $3.7 \mathrm{~m}$ led to an increase in capacity from 1940 to 2115 vehicles/hr/lane. In addition, increasing the median width from $8 \mathrm{~m}$ to $10 \mathrm{~m}$ led to an increase in capacity from 1900 to 1990 vehicles/hr/lane. Whereas in research [9] in terms of current speed, an increase in the lane width from $3.4 \mathrm{~m}$ to $3.7 \mathrm{~m}$ causes an increase in the current speed of $3.5 \mathrm{~km} / \mathrm{hr}$.

In the study conducted by Hashim 2012 with the title Effect of highway geometric characteristics on capacity loss, [4] indicates that the geometric is very influential on the maximum traffic capacity that can be passed by the vehicle, from the traffic density data on a road segment. When calculating the traffic density for 8.25 hours, the target position's traffic density is more significant (420 vehicles/hour) than the curve position (336 vehicles/hour).

\subsection{Road Capacity}

Capacity means that the maximum volume of traffic at some points of the road can across the unit of time under actual road and traffic conditions. Ability will affect the design, including the number of lanes and turning lanes, junction configuration, and traffic control. Capacity-related service levels vary depending on the setting and functional class of the road [10]. The design capacity is a road traffic volume service that performs and is generally used as the basis for road planning and design [1].

In research [2]carried out in Oslo and Alesund, there was land use development of $21.99 \%$ as well as the highest growth in employment in the expanded Moa region (46.6\%) and 
outer urban areas $(36.2 \%)$, less in the expanded downtown area $(5.1 \%)$ which led to a traffic flow growth of $30 \%$ in Oslo and 53\% in Alesund so that the conclusion is that additional road capacity is a necessary condition due to land use development that encourages the trip generation and attraction movement, which contributes to traffic growth and can lead to congestion

\subsection{Levels of Service for Road Transportation.}

Level of Service, LOS is a qualitative measure used to indicate traffic conditions in terms of speed, travel time, freedom of maneuver, comfort, convenience, traffic disruption, safety, etc. Too low service level indicates that traffic facilities provide poor operation and low speed, and road function is not realized [11]. The more the ratio, the bigger the congestion. A value of 1.0 indicates heavy traffic. LOS suitable for some scenarios is presented to deal with existing traffic problems [12].

In [13] study, a comparison was made based on the type of road and the total distance traveled by road type and then divided them to get the service level. The result is roads with a median of $2 / 1$ to better service level (0.7) than the motorway (0.9). This means that $2 / 2 \mathrm{TT}$ lanes equipped with barriers have less delay compared to traffic travel distances than other road types. This is also what happened to the Piet A. Tallo Street Kupang section, which will be studied. There is divided (4/2T), and then it becomes two lanes two way undivided (2/2TT).

\section{Research Method}

This research was conducted on the Piet A. Tallo street section in Kupang City with a capacity and performance analysis based on the Indonesian Road Capacity Guide 2014, PKJI 2014. Based on PKJI 2014, the capacity of urban road sections can be calculated using the empirical formula below.

$$
C=C_{0} \times F C_{L J} \times F C_{P A} \times F C_{H S} \times F C_{U K} .
$$

Where,

C = Capacity (pcu/hr).

$\mathrm{C}_{0} \quad=$ Basic capacity $(\mathrm{pcu} / \mathrm{hr})$.

$\mathrm{FC}_{\mathrm{LJ}}=$ Adjustment factor of capacity related to lane width or traffic lane.

$\mathrm{FC}_{\mathrm{PA}}=$ Adjustment factor of capacity related to direction separation (if undivided road).

$\mathrm{FC}_{\mathrm{HS}}=$ Adjustment factor of capacity related to side friction on shoulder or curb.

$\mathrm{FC}_{\mathrm{UK}}=$ Adjustment factor of capacity related to city size. 
The strategy to reduce traffic jam is carried out to improve the performance of the Piet A. Tallo street section. Then a 20 year condition projection is carried out so that the reduce of congestion problems can be carried out efficiently for the long term [14]. Primary data collected were geometric road data to analyze road section capacity, traffic flow data was taken using the manual traffic count method by surveyors from 06.00 to 19.00 recorded in 1 hour intervals, side friction data to determine side friction classes for the calculation of capacity and vehicle speed for the calculation of Space Mean Speed (SMS) as in formula (2) in order to determine the relationship with the degree of saturation ( $D_{J}$ ). With a case study, the space mean speed method is illustrated to be effective in estimating the travel speed for the entire road segment. By using this method, the travel speed or travel time of urban roads can be estimated more precisely [15]. To get the speed mean space of all vehicles occupying a section of the road during a certain period it can be calculated using the formula below.

$$
\bar{U}_{S}=\frac{L}{\frac{1}{n} \sum t_{i}}
$$

Where

$\mathrm{L} \quad=$ Length of the road section sample $(\mathrm{m})$.

$\mathrm{n} \quad=$ Number of vehicle samples.

$\mathrm{t}_{\mathrm{i}} \quad=$ Travel time of vehicle $(\mathrm{sec})$.

Secondary data in the form of population and number of motorized vehicles from 2014-2019 Kupang City were obtained from BPS Kota Kupang [16][17]. The data is used to project the growth of motorized vehicles in 2040. The projection uses data on the number of motorized vehicles in 2014-2019 in Kupang City which is modeled in the form of a linear regression then projected for the next 20 years, namely in 2040. To perform calculations using linear regression carried out with the help of Microsoft Excel which has data analysis facilities in which there is a linear regression calculation [18]. The general equation form of linear regression is as below.

$Y=a+b x$.

Where,

$\mathrm{Y}=$ dependent variable.

$\mathrm{X} \quad=$ independent variable.

$\mathrm{a} \quad=$ intercept.

$\mathrm{b}=$ coefficient. 


\section{Results and Discussions}

\subsection{Existing conditions.}

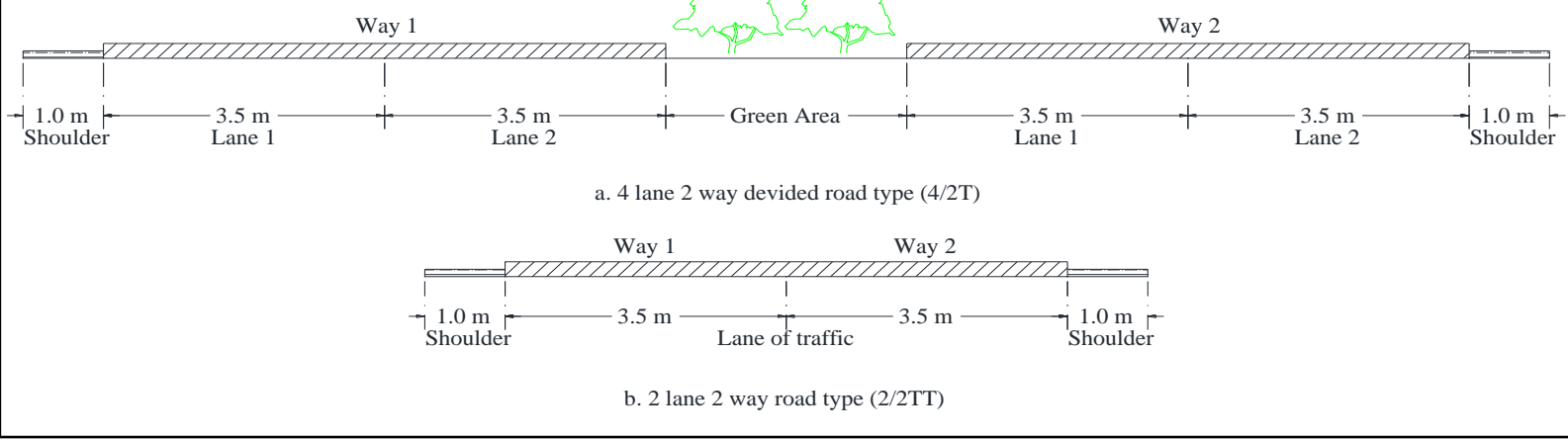

Source : Research Results, 2020.

Figure 1. Cross Section Of Piet A. Tallo Street.

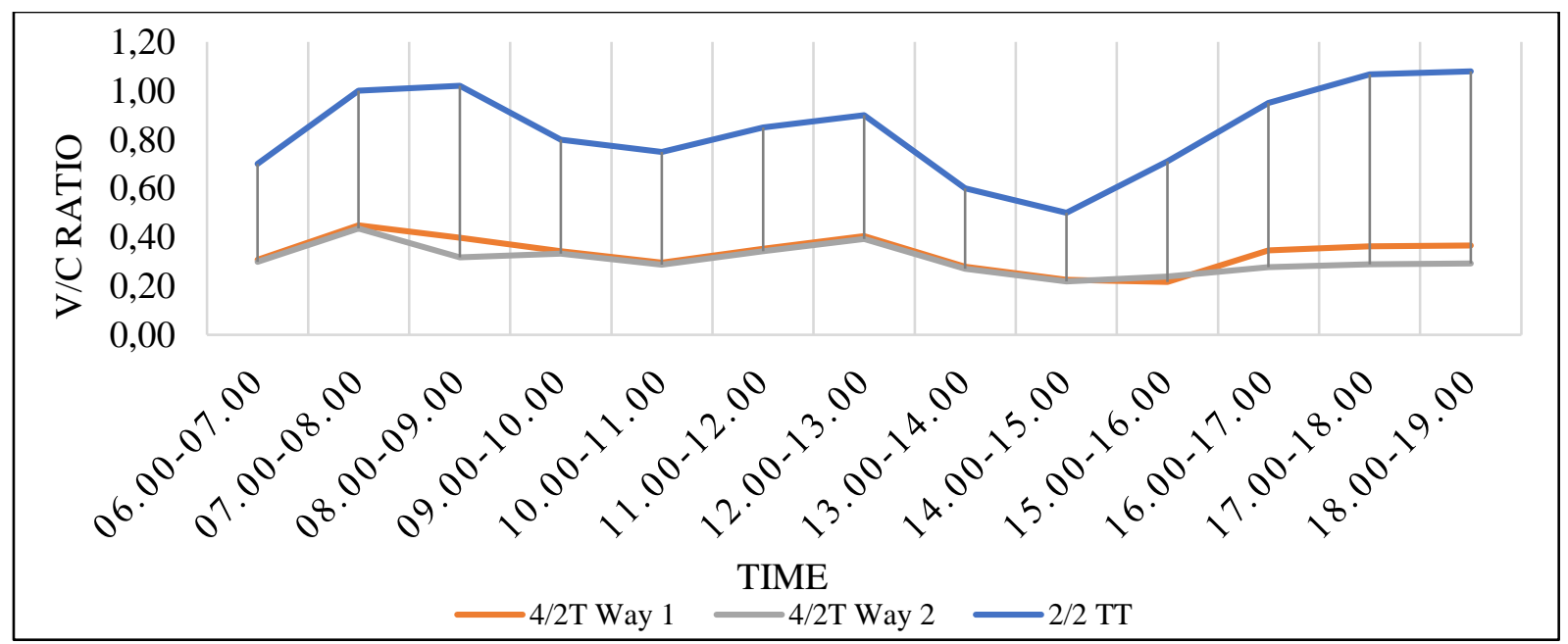

Source : Research Results, 2020.

Figure 2. V/C Ratio.

The Piet A. Tallo street section's condition consists of 2 types of roads, namely 4/2T and $2 / 2 \mathrm{~T}$. Figure 1. shows a cross-section of the two road types. Due to the change from $4 / 2 \mathrm{~T}$ to $2 / 2 \mathrm{TT}$, there is a reduction in road capacity. As a result, there is a buildup due to traffic that exceeds the road's capacity during peak hours. We can see that the higher the road network's service level, the greater the capacity of the road network. This is because the smaller the road network's saturation, the higher the speed of the vehicles, which causes the road network capacity to increase [19]. It can be seen in Figure 2. that the degree of saturation (DJ) in type 2/2TT reaches 1.08 at 18.00 to 19.00 while in type 4 / $2 \mathrm{~T}$ only reaches a maximum value of 0.48, which occurs at 08.00-09.00. 


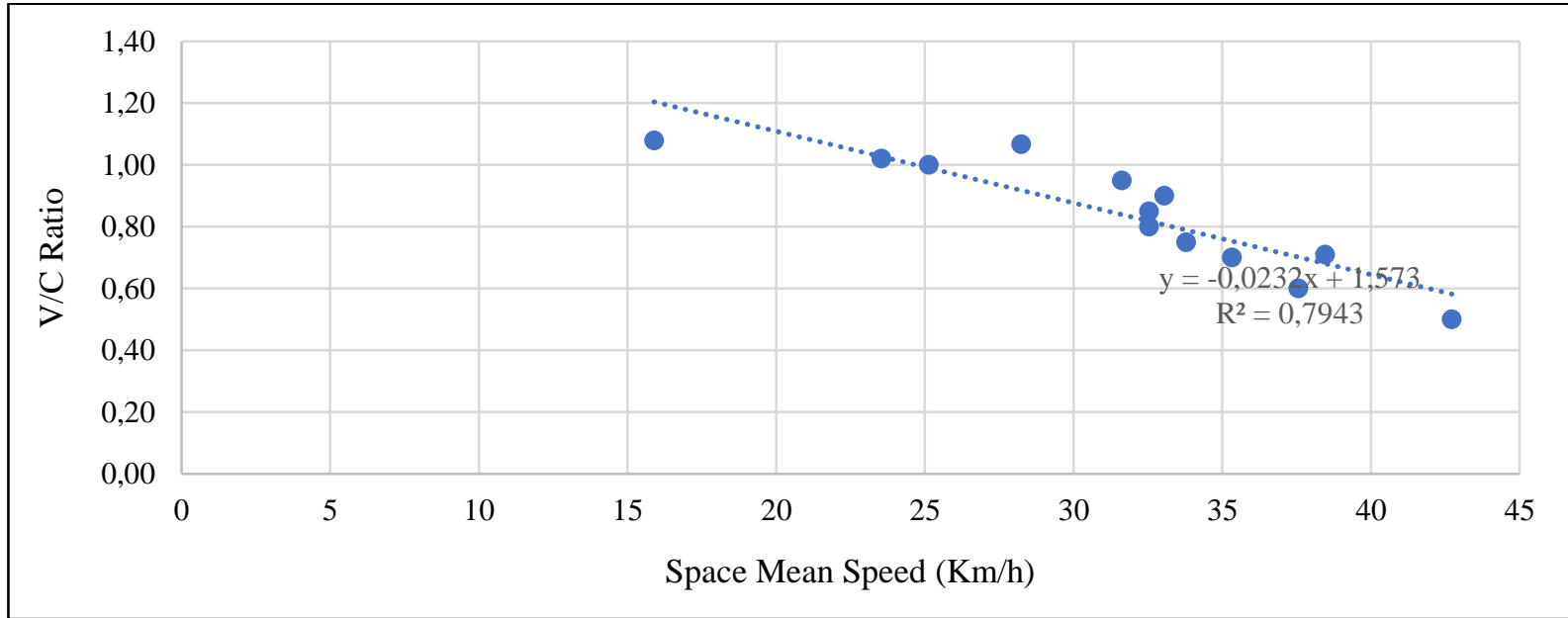

Source : Research Results, 2020.

Figure 3. Relationship Between V/C Ratio and SMS.

In Figure 3, it is shown that the degree of saturation, which is the ratio between traffic flow and road capacity, has an effect on $79.43 \%$ of the speed of vehicles crossing the Piet A. Tallo street. The lower the degree of saturation, the vehicle speed will increase. This shows that the main problem with congestion in this section is the reduced road capacity.

\subsection{Traffic Forecasting.}

In order for the resulting handling measures to have an impact over a long period of time, projections of traffic flow conditions are carried out in the next 20 years, namely in 2040 [14] by using data on the number of motorized vehicles in Kupang City from 2014-2019 as shown in Table 1. where KR is a light vehicle, KB heavy vehicle and SM motorcycle[16][20].

Table 1. Number Of Vehicles In Kupang City.

\begin{tabular}{cccc}
\hline \multirow{2}{*}{ Year } & \multicolumn{3}{c}{ Vehicle Type } \\
\cline { 2 - 4 } & KR & KB & SM \\
\hline 2014 & 10772 & 5030 & 110703 \\
2015 & 11590 & 5351 & 125574 \\
2016 & 13227 & 6045 & 158124 \\
2017 & 14061 & 6379 & 171129 \\
2018 & 14914 & 6766 & 183989 \\
2019 & 15929 & 7107 & 197211
\end{tabular}

Source : Research Results, 2020. 
Then a linear regression model was made to obtain a model of the growth trend of each type of motorized vehicle in Kupang City. By using the model in Figure 3., the peak traffic flow for each type of motorized vehicle that crosses the Piet A. Tallo street in 2040 is obtained, which is shown in Table 2. with the total number that crosses the Piet A. Tallo street section are light vehicles (KR) 2666 vehicles/hour, heavy vehicles (KB) 67 vehicles/hour and motorcycles (SM) 12684 vehicles/hour.

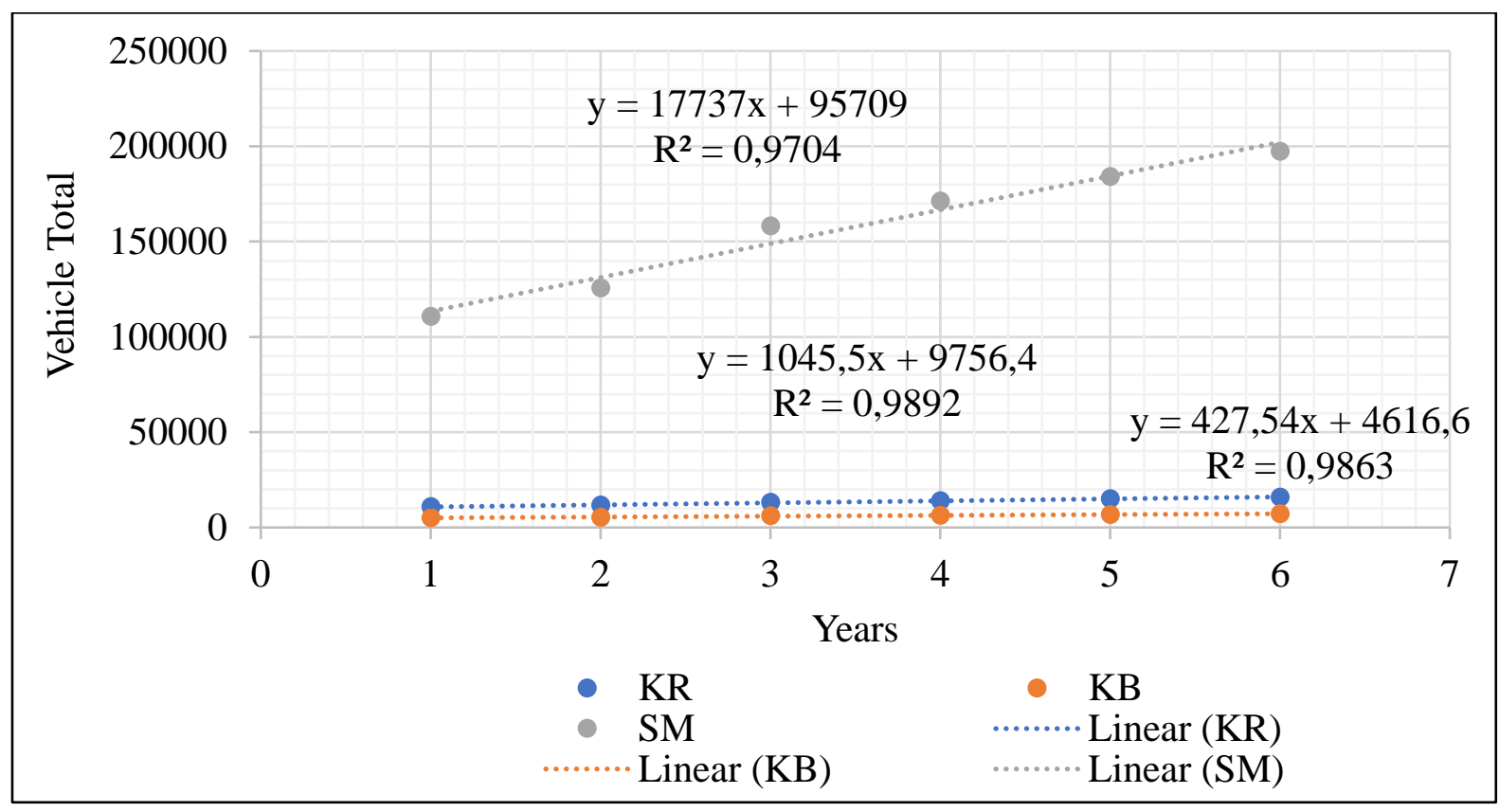

Source : Research Results, 2020.

Figure 4. Growth Model of Vehicle.

Table 2. Total Peak Traffic Flow on Piet A. Tallo Street in 2040.

\begin{tabular}{cccc}
\hline \multirow{2}{*}{ Vehicle type } & \multicolumn{3}{c}{ Number of vehicles } \\
\cline { 2 - 4 } & Way 1 & Way 2 & Total \\
\cline { 2 - 4 } & Veh/h & Veh/h & Veh/h \\
\hline KR & 1097 & 1569 & 2666 \\
KB & 43 & 24 & 67 \\
SM & 5747 & 6937 & 12684 \\
\hline
\end{tabular}

Source : Research Results, 2020.

By using traffic flow data at peak hours in 2020 with the same road infrastructure conditions as the existing conditions, it can be seen in Figure 5 the performance conditions of the Piet A. Tallo street section for each type of road (2/2TT and 4/2T) in 2040 if no handling steps are taken (do nothing). 


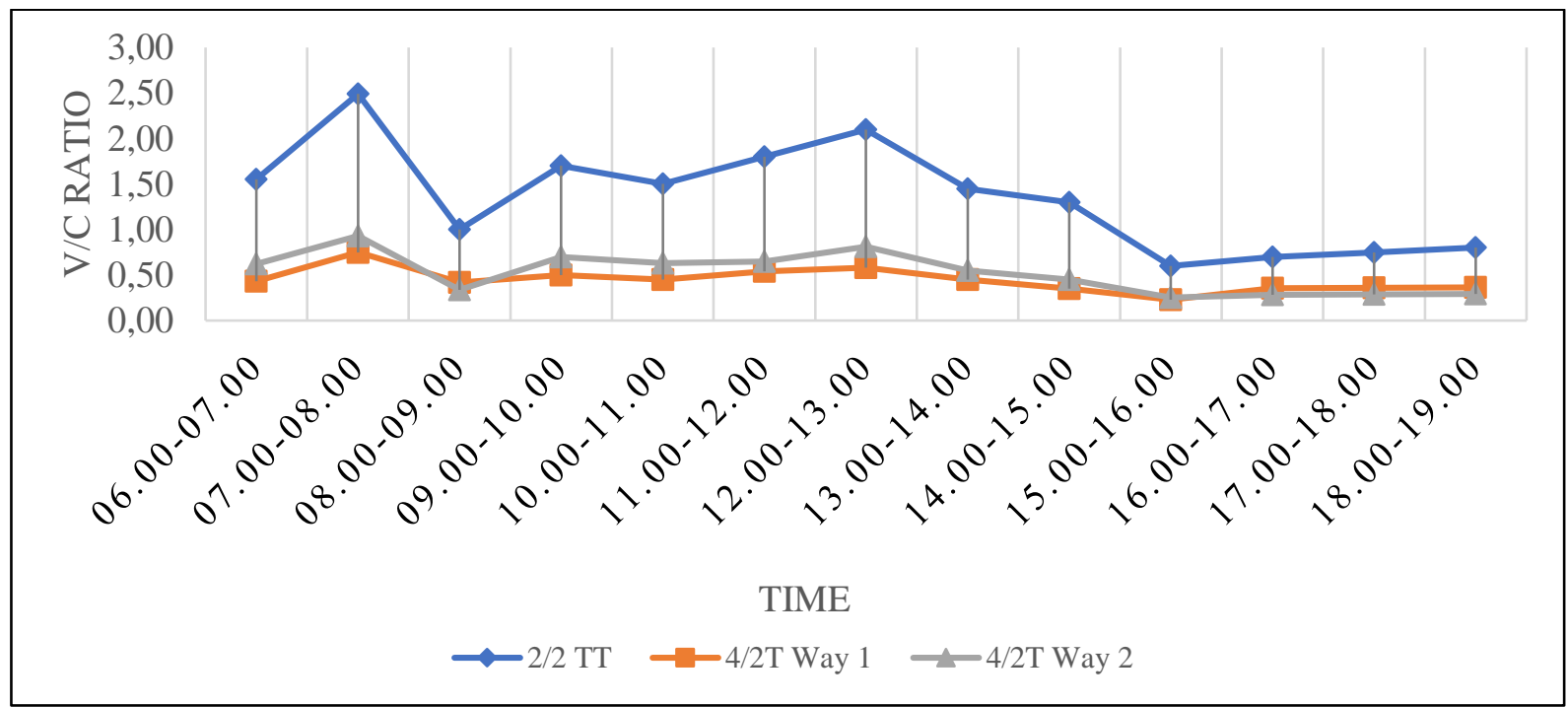

Source : Research Results, 2020.

Figure 5. V/C Ratio of the Piet A. Tallo street in 2040 (do nothing).

Based on Figure 5. the segment which is still 2/2TT is no longer feasible because the ratio between traffic flow and road capacity has reached 2.49 , which means that the traffic flow of $5919 \mathrm{pcu} / \mathrm{hour}$ across the Piet A. Tallo street in 2040 has exceeded The capacity is only $2379.80 \mathrm{pcu} / \mathrm{hour}$.

\subsection{Strategy to Solve Congestion.}

The traffic operating characteristics are significantly affected if there is heterogeneity in the traffic mix. This impact has further exacerbated the two-lane two-way road, where the interaction between vehicles occurs in both directions. Hence, the capacity of these roads varies widely depending on the number of interactions [21]. The main problem that is happening to the Piet A. Tallo street section is the lack of road capacity to serve traffic flow. Therefore, increasing the capacity of roads must be done [22], namely by controlling parking in the area around the Liliba bridge, which has an impact on the condition of the side friction, which is better (lower) by continuing to use the 2 / 2TT type of road but the results show the DJ value of 2.34 which means capacity is not sufficient to be able to serve traffic flow in 2040. Therefore, it is necessary to change the segment 2 / $2 \mathrm{TT}$ to $4 / 2 \mathrm{~T}$. By changing the road type from 2.2TT to 4 / 2TT, it is necessary to construct one bridge with one side of the existing Liliba bridge, so that each 2-lane bridge can be traversed by traffic in one direction. In the study [23], side friction affected the reduction of road capacity significantly (up to 60.73\%) from the road base capacity. Therefore, in Figure 6, the blue area is a culinary area, so controlling vehicles entering and leaving and parking vehicles in that area will have an impact on increasing road capacity, and 
the plan to add blue lanes is an additional position for the bridge so that later the Piet A. Tallo street road type will all have type 4 / $2 \mathrm{~T}$ so that later there will be no more vehicle buildup as is currently the case which is still typed 2 / 2TT.

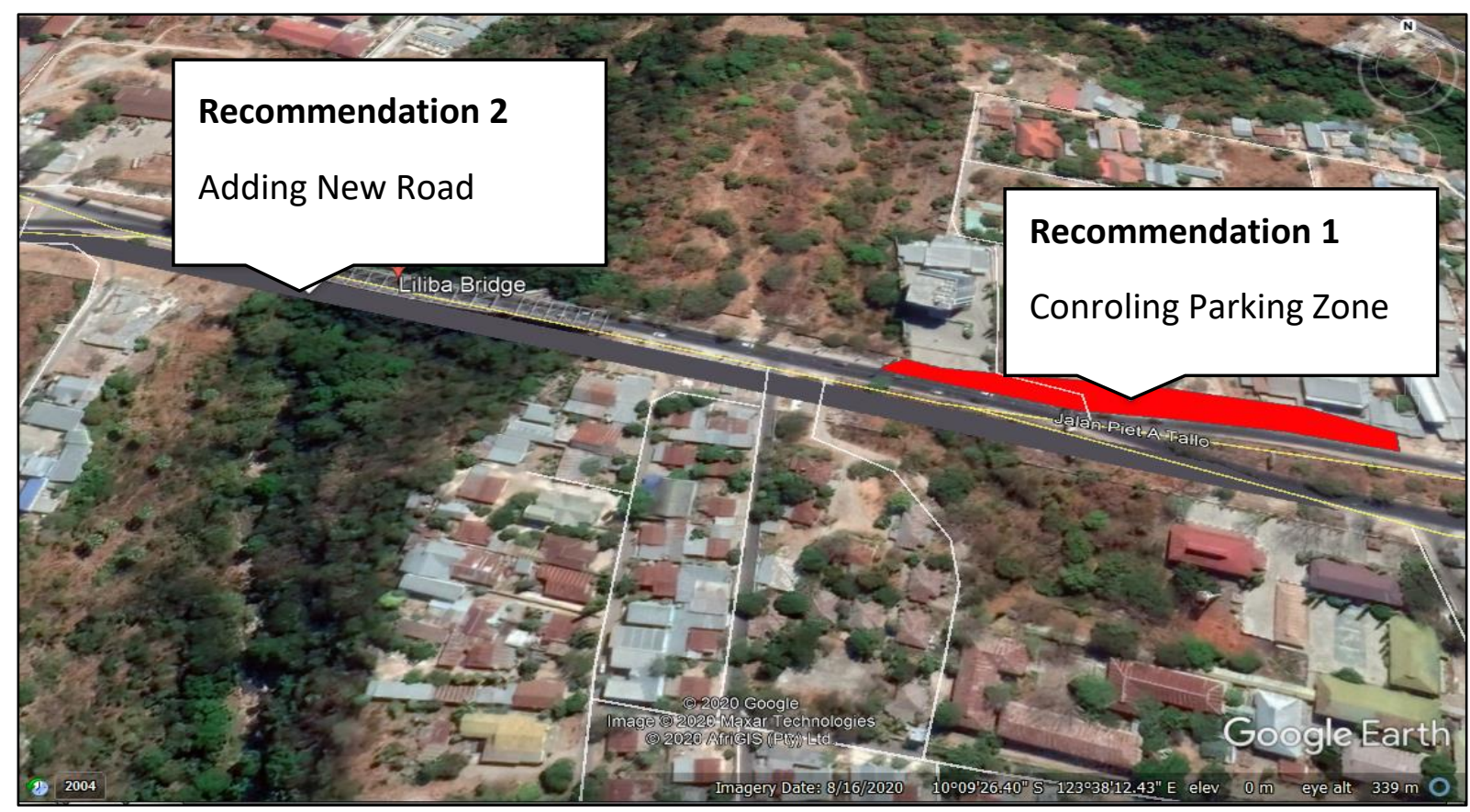

Source : Google Earth, 2020.

Figure 6. Recommendations for Change of Road Types and Control of Side Barriers.

Referring to the Indonesian Road Capacity Guidelines[24] for divided road types (4 / $2 \mathrm{~T}$ and $6 / 2 \mathrm{~T}$ ) the capacity analysis is carried out per lane of each traffic direction, so after changing the road type to 4 / 2T for each direction, it has a capacity of $3599.64 \mathrm{pcu} / \mathrm{hour}$.

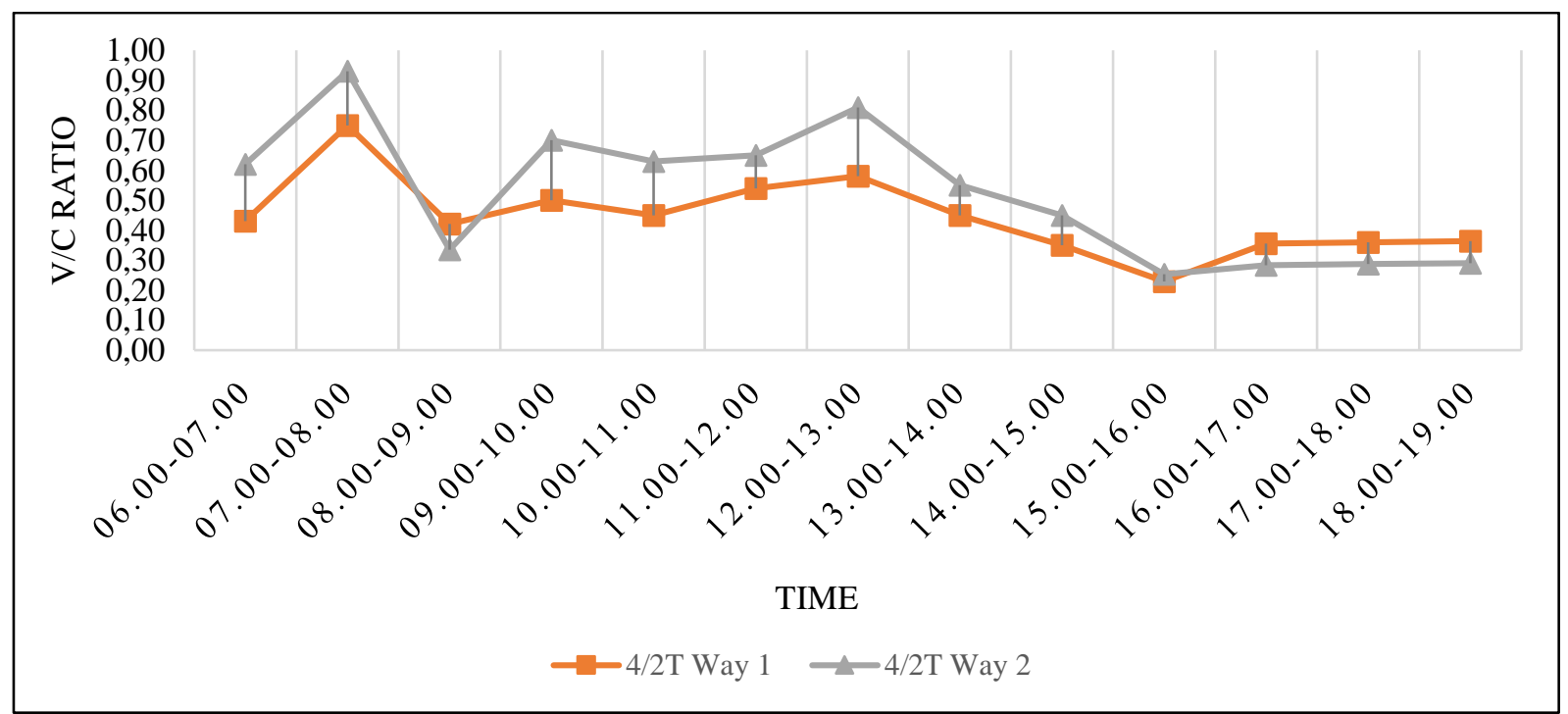

Source : Research Results, 2020.

Figure 7. V/C Ratio (After Implementation of Recommendations). 
Based on Figure 7, after increasing the capacity by changing the type 2/2TT segment to $4 / 2 \mathrm{~T}$, the comparison value between traffic flow and capacity or the degree of maximum saturation on the Piet A. Tallo street reaches to 0.93 , which means that the segment capacity is still able to serve traffic flow until 2040.

\section{Conclusion and Suggestion}

\subsection{Conclusion.}

The conclusions obtained from testing the Strategy To Reduce Traffic Jams on Piet A. Tallo Street, Kupang City are as follows :

1. The main cause of traffic congestion on the Piet A. Tallo street section is the lack of road capacity in the 2/2TT segment to serve traffic flow with the ratio of traffic flow and capacity (V/C Ratio) reaching to 1.08 .

2. Projection of the condition of the Piet A. Tallo street section in the type 2/2TT segment in 2040 without a solution, the traffic flow has exceeded the capacity of the existing road sections with a DJ value of 2.49 .

3. Increasing capacity by curbing side friction in the control of parking vehicles in the area around the Liliba bridge and by changing the road type to type 4/2T, in 2040, the road capacity can still serve existing traffic flows with the ratio between flow and capacity only reaching to 0,93 .

\subsection{Suggestion.}

Suggestions for further researchers obtained from testing are that researchers can analyze the benefits of changing the type of road from 2/ 2TT to 4 / 2TT by taking into account the Liliba Twin Bridge's construction costs. 


\section{References}

[1] X. Wu and X. Du, "Research and Practice on Equilibrium Theory of Road Capacity," Procedia - Soc. Behav. Sci., 2013, doi: 10.1016/j.sbspro.2013.08.172.

[2] A. Tennøy, A. Tønnesen, and F. Gundersen, "Effects of urban road capacity expansion Experiences from two Norwegian cases," Transp. Res. Part D Transp. Environ., 2019, doi: $10.1016 / j . t r d .2019 .01 .024$.

[3] A. I. Candra, "STUDI KASUS STABILITAS STRUKTUR TANAH LEMPUNG PADA JALAN TOTOK KEROT KEDIRI MENGGUNAKAN LIMBAH KERTAS," UKaRsT, vol. 2, no. 2, p. 11, 2018, doi: 10.30737/ukarst.v2i2.255.

[4] I. H. Hashim and T. A. Abdel-Wahed, "Effect of highway geometric characteristics on capacity loss," Jiaotong Yunshu Xitong Gongcheng Yu Xinxi/Journal Transp. Syst. Eng. Inf. Technol., 2012, doi: 10.1016/s1570-6672(11)60223-7.

[5] P. Kumar, S. Arkatkar, and G. Joshi, "Developing Level of Service (LoS) Thresholds on Ten-Lane Divided Multi-Lane Urban Roads in India,” 2018, doi: 10.1061/9780784482025.066.

[6] M. E. Bolla, Y. A. Messah, and M. M. B. Koreh, “Analisis Daerah Rawan Kecelakaan Lalu Lintas (Studi Kasus Ruas Jalan Timur Raya Kota Kupang),” J. Tek. Sipil, 2013.

[7] S. Chen et al., "Understanding road performance using online traffic condition data," $J$. Transp. Geogr., 2019, doi: 10.1016/j.jtrangeo.2018.12.004.

[8] A. M. Semeida, "New models to evaluate the level of service and capacity for rural multilane highways in Egypt,” Alexandria Eng. J., 2013, doi: 10.1016/j.aej.2013.04.003.

[9] K. Fitzpatrick, K. Dixon, and R. Avelar, "Evaluating operational implications of reduced lane and shoulder widths on freeways," J. Transp. Eng., 2016, doi: 10.1061/(ASCE)TE.1943-5436.0000884.

[10] D. J. Findley, "Highway Geometric Design," in Highway Engineering: Planning, Design, and Operations, 2016.

[11] Y. Yan, Z. Ning, H. Li, and D. Wang, "Urban Expressway Functional Reliability," J. Highw. Transp. Res. Dev. (English Ed., 2016, doi: 10.1061/jhtrcq.0000504.

[12] R. Gajjar and D. Mohandas, "Critical Assessment of Road Capacities on Urban Roads A Mumbai Case-study,” 2016, doi: 10.1016/j.trpro.2016.11.124. 
[13] T. Bergh, M. Remgård, A. Carlsson, J. Olstam, and P. Strömgren, "2+1-roads Recent Swedish Capacity and Level-of-Service Experience," 2016, doi: 10.1016/j.trpro.2016.06.028.

[14] A. Wadu, R. Kusumawardhani, and I. Suherminingsih, "MANAJEMEN LALU LINTAS DI JALAN LINGKAR KAMPUS UNIVERSITAS BRAWIJAYA,” JUTEKS - J. Tek. Sipil, 2019, doi: 10.32511/juteks.v3i2.277.

[15] H. Liu and X. Guo, "Calculating method on the travel speed for urban expressway," 2012, doi: $10.1061 / 9780784412435.026$.

[16] M. Sri Wiwoho, M. Machicky, R. Nawir, Indrawan, and S. Ikhsan M., "Bamboo Waste as Part of The Aggregate Pavement The Way Green Infrastructure in The Future," MATEC Web Conf., vol. 138, p. 03013, 2017, doi: 10.1051/matecconf/201713803013.

[17] Z. Mubarok, K. Murtilaksono, and E. D. Wahjunie, "Response of Landuse Change on Hydrological Characteristics of Way Betung Watershed - Lampung," J. Penelit. Kehutan. Wallacea, vol. 4, no. 1, p. 1, 2015, doi: 10.18330/jwallacea.2015.vol4iss1pp1-10.

[18] H. Wibisana and N. Utono, "Pemetaan Kecepatan dan Kerapatan Lalu Lintas di Ruas Jalan Arteri Kota Surabaya,” J. Tek. Sipil, 2019, doi: 10.28932/jts.v12i2.1420.

[19] Z. Qu, Y. Xing, H. Hu, X. M. Song, and Y. Z. Duan, "Study on the relationship between urban road network service level and capacity,” 2012, doi: 10.1061/9780784412442.098.

[20] E. I. Olalekan et al., "study examines role of indigenous knowledge system in land management," Ecol. Econ., vol. 1, no. 1, pp. 1-7, 2012, doi: 10.1017/CBO9781107415324.004

[21] N. Roy, R. Roy, H. Talukdar, and P. Saha, "Effect of Mixed Traffic on Capacity of TwoLane Roads: Case Study on Indian Highways,” 2017, doi: 10.1016/j.proeng.2017.04.349.

[22] N. Wu and K. Lemke, "A new model for level of service of freeway merge, diverge, and weaving segments," 2011, doi: 10.1016/j.sbspro.2011.04.438.

[23] S. Biswas, S. Chandra, and I. Ghosh, "Side friction parameters and their influences on capacity of Indian undivided urban streets," Int. J. Transp. Sci. Technol., 2020, doi: 10.1016/j.ijtst.2020.03.007.

[24] D. A. Limantara, Y. Cahyo, S. Purnomo, and S. W. Mudjanarko, "Pemodelan Sistem Pelacakan LOT Parkir Kosong Berbasis Sensor Ultrasonic Dan Internet Of Things ( IOT ) Pada Lahan Parkir Diluar Jalan," Semin. Nas. Sains dan Teknol., vol. 1, no. 2, pp. 1-10, 2017. 